E 112 V67 

$y$

4 ,

(i)

से के

is

sint

$y$

8

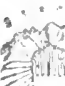

4

3

$\therefore$

S

$\because 0$

$\mathrm{C}_{\gamma}$

is

E.

a 





\section{COLUMBUS A SPANIARD AND A JEW}

$\mathrm{By}$

HENRY VIGNAUD

REPRINTED FROM THE

Amerian fistonical fantow

VOL. XVIII., NO. 3

APRIL, 1913 
EU⿱

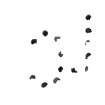




\section{COLUMBLS A SPANIARD AND A JEW ${ }^{1}$}

Sone twelve or fifteen years ago, a Spanish scholar. Don Garcia de la Riega, a principal citizen of I'ontevedra in Galicia, whose name has been given to one of the streets of that town, discovered from the local archives that in the fifteenth century a family was established there of the name of Colon, several members of which bore the same forenames as are to be found among the Colombos of Genoa, the kinsmen of Christopher Colmmbus. In I 434 and in 4437 , there was at Pontevelra a Doningo Colon; in 14.38 a Bartolomé Colon: in 1496 a Cristobo Colon; in 1434 a Blanca Colon. Now, Domenico was the name of the father of the discoverer of America, who had a younger brother called Bartolomeo, and a sister called Bianchinetta. Furthermore, Señor de la Riega found out that during the same period there was at Pontevedra a Fonterossa family who had relations with the Colons, and who were Jews, if we are to judge by their Biblical forenames.

Struck by these interesting coincidences, he asked himself if this Domingo Colon of Pontevedra might not possibly be the father of Christopher Columbus, and if Christopher himself, about whose birthplace there has been so much discussion, might not have been born in Galicia, instead of in Genoa, as everyone has come to suppose; and might it not also be that the Discoverer's mother, whose name of Susanna is Jewish and whose fanily name of Fontenarossa closely resembles that of the Jewish family of Fonterossa of Pontevedra, was herself of that same family?

Clearly the documents which have been brought to light establish nothing of the kind; but, in the absence of explicit deeds to that effect, one may always fall hack on hypothesis, which has precisely for its olject the supplying of absent proofs. Let ns suppose, for instance. that the Domingo Colon of Pontevedra married the daughter

${ }^{1}$ Cristubal Colon Español! Conferencia por Colso Garcia de la Riega en sesión publica celebrada por la Sociedarl Geografica de Madrid. Madrid, tipografico de Forlenet, $1898,17.43)$.

La l'crdadera Patria de Cristúbal Colon. Por Fernando de Antín del Olmet. (La España Moderna. Junio, 1910. Madrid).

The Secret of Columbus. By lyyland C. Kirk. (Washington, Hayworth, 1912, pp. 62).

La lerdudera Cuna de Cristóbal Colon. Por el Dr. Constantino de llortat y Pardo. (New York, John B. Jonathan, 1912, 11). 96 ). 
of a Fonterossa; that this girl was called Susanna, which was the name of Columbus's mother; that from this marriage came several children, the elder two of whom were Christopher and Bartholomew; and, finally, let us suppose that between the years I444 and I 450, a period when troubles broke out in Galicia, Domingo, his wife Susanna, and their sons Christopher and Bartholomew left their native land and took refuge in Genoa, there changing their Spanish name of Colon into its Italian form of Colombo.

Accept as facts all these suppositions and at once no further uncertainty remains; matters being thus arranged, assume the form it is desired to give them, and Columbus becomes a Spaniard from the place of his birth and a Jew by blood as well on his mother's as on his father's sicke, for it is the custom of Israelites to intermarry among themselves.

Señor de la Riega next proceeds to study the question, and, as we are told, after long and minute researches he becomes convinced that things had happened just as he had supposed, and that the Colombos of Genoa, the father, mother, and brother of Christopher, as also Christopher himself, were no other than the Colons of Spain, and Jews of Pontevedra.

It was to set forth this thesis that he gave a lecture, several times repeated and always welcomed with applanse, before the Geographical Society of Madrid; it was in order to make it more widely known that Señor Anton del Olmet made it the subject of a literary article in La España Modema; it was with a view to propagating it that Professor Hyland C. Kirk, of Washington, wrote The Secret of Columbus, and it was with the same motive that a learned gentleman of Cuba, Dr. Constantino Horta y Pardo, had 25.000 copies of his pamphlet La I'crdadera Cuna de Cristóbal Colon printed and sent to all the govermments, learned societies, and distinguished personalities, with a circular in four langtlages in which the recipients are entreated to move heaven and earth-Que Remoricndo Ciclo $y$ Ticrra-in order to spread the tidings that Columbus was born in Spain, in the province of Galicia!

What is even more extraordinary than this noisy propaganda is the complacency with which was welcomed a thesis absolutely at variance with historic data accepted by all the world. In fact, apart from a few Italian publications, it was nearly everywhere received as an interesting revelation which would change history on a point which had been considered as definitely settled.

It is time to restore things to their places, and we proceed to do so as briefly as possible. 
Withont pausing at what is improbable in the suppositions to which Señor de la Riega is driven in order to set his thesis on its feet, we shall confine ourselves to pointing out two weighty objections which forcibly tell against its acceptance. The first is the existence of anthentic documents which reveal to us the family of Columbus established in the territory of Genoa from I 429 ) until the end of the century and even beyond it. The second is the testimony of Columbus himself, of his son Ferdinand, and of the greater part of his contemporaries, that he was a Genoese.

These documents and evidences are so numerous and explicit that there is but one way to set them aside, and that is to deny that the first relate to our Colmubus, and to misrepresent the second. Señor de la Riega and his followers have not hesitated to adopt this method. As it is proved that there existed in all the Latin countries numcrons families bearing the names of Colon, Conlon, and Colombo, three variants of the same word, they assure us, that the Genoa Colombos, looked upon as the kinsfolk of Columbus, had really nothing to do with him, that the Domenico Colombo, weaver of Genoa and Savona, mentioned in these documents was not his father, and the Christoforo, son of Domenico and weaver whom they likewise mention, refers to some other person than the I)iscoverer. Such an assertion signifies that conscientions scholars like Staglieno, Belgrano, Desimoni, Salvagnini, Lollis, Harrisse, and others, who for years have examined, studied, and expounderl these documents, have committed the grave error of attributing to Columbus a father, mother, brothers, a sister, an uncle, and consins who were strangers to him. This appears so extraordinary that one waits with curiosity the proofs of so downright a condennation of so many learned works carried on for many years, and justly estecmed. Let us see in what their proofs consist.

Among the Italian documents referring to Cristoforo Colombo. son of Domenico, one of the most important bears the date of I 470 , ancl therein he is represented as being nineteen years of age, therefore placing his birth in the year 1451 , that is to say at a period later than the one in which he is supposel to have left Ponteredra with his father, mother, and brother. This docment, we are airily told, does not relate to the Discoverer. Why? Riecause, accorling to Pernaldez who knew him personally, he was born in 1436 and was therefore thirty-three or thirty-four years old in 1470 . lint the evidence of Permaldez is not to be acepted here, for among other reasons which prove him to be mistaken, there is one that is decisive; this is the existerle of a doctment, discovered some years and coming from Colmmbn himself, wherein he declares, in 1479 , that he 
was then over twenty-seven years of age, which confirms the first date. $^{2}$

The Colombo who made this declaration, we are again told, is not our Christopher, who in I 479 was much older than twenty-seven. Señor de la Riega and those who adopt his views might have said to themselves that if Columbus was born in 1436 there was an interval of twenty-five years between his birth and that of his brother, a fact which would be quite abnormal. We possess as a ntatter of fact a deposition by Bartholomew, dated I5 5 , in which he states that he was then over fifty years of age. ${ }^{3}$ Bartholomew was therefore born in I 46 I or I 462 , and consequently could not have left Pontevedra between 1444 and 1450 with his brother Christopher who was not himself then born.

These reasons are not the only ones we are given in order to deny that the Colombos of Genoa were of the family of Colmmbus. Here are some others. If the Colombos had been of kin to the Discoverer, they would not have failed, so we are informed. to put in their claims when he had become a great personage, which they do not appear to have done. What then signify the legal documents whereby the creditors of Domenico, who had died intestate, subpoena as responsible his sons Christopher and Bartholomew and Diego, all of whom, according to the said documents, were then in Spain?4 We are answered that these documents are apocryphal. Well, then, is that also a forged document wherein Giannetto, Natteo, and Amighetto Colomloo, sons of Antonio Colombo, Domenico's brother, agree to send one of themselves to their cousin Christopher, admiral in Spain-" amiratum regis Ispanie "-to solicit his protection? ${ }^{5}$

The deeds of $I_{472}$ mentioning Cristoforo Colombo, son of Domenico, and wool-stapler at Genot-"lanerio de Janua "-also do not refer to the Discoverer they say, because he was then in Portngal and was abont to marry. But, since the discovery of the deeds produced by Salvagnini, it is lemonstrated that Columbus landed for the first time in Portugal in $I+75$, and that it was not until after February, I47\%, that he was able to establish himself in Lisbon,

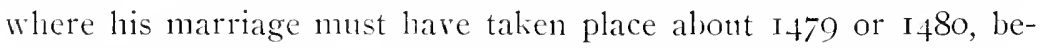
cattse on his arrival in Spain in $\mathrm{I}_{4} 84-\mathrm{I} 485$ with his son Diego, the latter was still a little boy.

These are the proofs given by our atthors in order to show that

see this document in the Americax Historical Review, XII. 277-279 (January, 1907).

${ }^{3}$ Los Plcitos dé Colon (Madrid, i 892 ). I. I 82.

${ }^{4}$ Raccolta Colombiana. Documenti, nos. S9 and 90.

I Ibid., no. 83 . 
the Colombos of Genoa were not of the Discoverer's family. The method they employ for the purpose of establishing as a fact that the contemporaries and friends of Columbus did not look on hin as a Genoese is even more astonishing. We run rapidly through what they say on this point.

On two separate occasions Columbus has himself written that he was born in Genoa, "jo nacido en Genova ", and, "en clla naci"." This, we are told, is of no value because it suited Columbus to give himself ont as being a Genoese, for had it been known that he was a Jew from Pontevedra he would have been persecuted by the Inquisition. Moreover, it is added, his statement is contradicted by the testimony of a great many people.

Let is run through this testinony. In the first place the son of Columbus is himself called as a witness, becanse in the life he wrote of his father he feigns not to know his birthplace. This is incorrect. In a particular passage of his book, the only one quoted by our authors, he speaks, it is true, of doubts which have been thrown on this point. But for him these doubts do not exist, for further on he states that at Lisbon his father found scveral of his Genoese countrymen, " della sua nazione Genovese ", and in his will he thus describes himself: "Don Fernando Colon, hijo de D. Cristóbal Colon Ginovés.".s

Let us turn to the younger brother of Columbus, to Bartholomew. One of these learned gentlemen informs us that he was born in Portugal, and this, he adds, justifies the belief that Christopher was also a native of that place: and, as proof of the fact, he quotes Gallo, a distinguished Genoese, who had intercourse with the Colombo family, and who wrote: "sed Bartolomens minor natu in Lusitania". Gallo did in fact write these words, but he added: "demum Ulissipone constiterat", the full rendering leing: Bartholomew, the younger in birth-" minor natu" - at length settled at Lisbon in Portugal. Anyone may see that this is nut quite the same thing. But our authors are tenacious, and having once scheduled an error, they stick to it. Not only, they further assure us, has Gallo said that Bartholonew was horn in Portugal, but he makes the same statement about Cluristopher, and Bishop Ginstiniani confirms his testimony. Indeed! Gallo has written, " (hristoforus et Partolomeus fratres natione ligures ac Genue "," and Giustiniani says,

\footnotetext{
"Deed establishing the entailed estate, Navarrete, II, 22S, 232.

${ }^{7}$ Historic, ch. V.

"Col. Doc. Ined, XVI. (Madrirl, i\$59), 455.

"Gallo, in Kaceoltu. Fonti, II. iss.

Ibid.
} 
"Christofori Colum Genuensis". ${ }^{11}$ If that be not sufficiently clear, so far as the younger brother of Columbus is concerned, we have his own declaration that he was a Genoese in verses he wrote upon a map he had made for King Henry VII., "Genua cui patria est."12

Among other contemporary writers who do not appear to have said that Columbus was a Genoese our anthors boldly enlist the following:

Peter Martyr, who in one passage states that Columbus was a Ligurian, and further on makes this precise by writing he was "Genuensis": 13 Las Casas, who records that Columbus was "Genovés de nación"; "14 Oviedo, who wrote, "fue natural de la provinçia de Liguria, que es en Italia, en la qual cae la cibdad é señoria de Génova "; ${ }^{15}$ and Geraldini, who was a patron of Columbus, and who describes him as an Italian by nationality and a Genoese of Liguria, " Cienua Liguria". ${ }^{16}$

These are not the only witnesses. It may lue said that the greater part if not all of the writers of the fifteenth and the beginning of the sixteenth centuries, who mention Colnunbus, consider him as being a Ligurian and Genoese. It is the same with modern authors whose opinions carry weight in this matter, and, as our anthors are pleased to include Harrisse and myself among them, I beg to state that I never wrote that Columbus "no habia nacido en Genova". In full agreement with I Jarrisse, I have said exactly the opposite.

The quaint manner of quoting the written opinions of authors is not the only strange thing characterizing these publications to which our attention is called with so great a din., For example, one ascertains with astonishment that critics who are anxious to correct the history of Columbus on an essential point are but ill informed upon a number of particulars in his life which are now thoroughly elucidated. Thus, they still believe that he was born in 1436 , that he first went to sea when fourteen years old, that he sailed on every sea for a quarter of a century, that he commanded a galley for King René, that le appeared before the University of Salananca, and other similar legends which modern research and criticism have long swept from the pages of history. On the other hand, they know nothing of facts established by the testimony of documents now at the command of every reader.

They tell us that Diego. Columbus's eldest son, could not have been born in Portugal inasmuch as he knew not where was buried

\footnotetext{
${ }^{11}$ Raccolta, Fonti, II. 345.

${ }^{12}$ Las Casas, I. 225.

is Second decade, looki vis.

it I. 42 .

15. Book II., ch. II.

16 Intratrium, P. 302 .
} 
his mother, whom neither he nor his father has anywhere mentioned. ${ }^{17}$ Now Colmmbus has twice spoken of his wife: in a letter written at the end of 1500 and in his will. ${ }^{18}$ As to Diego, he states in his will that his mother is buried in the Camelite Convent of Iisbon, and he expresses the wish that her remains be translated to Hispaniola. ${ }^{10}$

Their interpretation of a number of very simple facts is no less astonishing. All that they say about the Santa Maria, which Columbus calls the Galcga, because she was built in Galicia, and about the names of Porto Santo, San Salvador, and Trinidad as coming from places so called in Pontevedra, lacks even common sense. The same may be said for their reasons why the name Hispaniola was conferred upon Haiti. According to them, Columbus chose this name because he was a Spaniard, otherwise, had he been an Italian or Genoese, he would have christened that isle Italiana or Genoresa!

Need we further quote among the proofs they arlduce as to the Galician origin of Columbus that his real name was Colon, which is Spanish, and not Colombo, which is Italian; that in Portugal he passed himself off as being a Portuguese, and that finally those who say he was a Ligurian thereby admit he was a Spaniard, for Liguria is a synonym of Spanish origin!

One might criticize very many other remarkable statements in these publications wherein may be found at every page, so to speak, counterfeit assertions, false quotations, illogical deductions, and queer conjectures. Put we have said enough to satisfy the reader that of all these authors who have written to establish that Columbus was a Galician of Hebrew origin, it is only necessary to retain the simple facts of the existence at Pontevedra in the fifteenth century of a Colon family of which several individuals bore the same forenames as did those of the Colombo family of Genoa, and of a Fonterossa family whose name recalls the family of the 1)iscoverer's mother, which Fonterossa family was probably Jewish.

There is in reality nothing at all extraordinary about these facts. The Colons swarmed throughout the Latin countries. Among families of this name appear several Domenicos, several Partolomeos, who were not of Genoa. Nor were Jewish Colons wanting in Spain. Three were burned in Taragona in I for, that is in Columbus's own day, and it was possible for lim to have witnessed their suffering. The Colons of I'ontevedra were probably Israclites; but in order to see in them the Colons of Genoa it is necessary to distort well-known facts and falsify the evidence of contenmoraries. It is the same

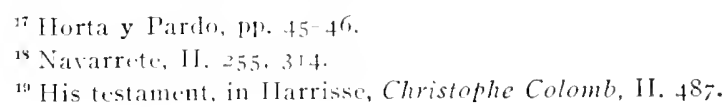


with regard to the Fonterossa of Pontevedra in Galicia. Because several of them bore Biblical names and because the mother of Columbus was called Susanna Fontenarossa we are not entitled to conclude as to the identity of the two families, and consequently as to the Hebrew origin of our Columbus. The name Fontenarossa is purely Italian and we know whence it comes; it derives from the valley of Fontenarossa to the northeast of Genoa where still exists a considerable market town of the name, and from it came the mother of Columbus. As to her name of Susanna, many Christian women have borne it and many bear it still.

Doubtless, in any case, it will be thought these were very poor reasons for making a Jew of Columbus; but our authors give others. Thus, this great man wrote in a Biblical style; he was fond of quoting the prophets; by choice he preferred to read books that were either Biblical or of Jewish origin; he himself wrote a book or prophecies: his mystical signature seems to recall some Jewish doctrine; Giustiniani says he was born of plebeian parents, which signifies they were miserable and low! Columbus left a legacy to a Jew; Jews protected him; he was avaricions; he thought himself the messenger of Jehovah; finally, he had a fresh colored complexion, fair hair, and aquiline nose, characteristics, as all the world knows, of the Israelite type, and particularly of the southern Jews.

We have dwelt at some length on this singular thesis because it has taken so considerable a development that it was to be feared it might, from the force of bold repetition under different forms and in various languages, end in obtaining credit among those who were not well acquainted with the subject. We have thought it our duty to restore things to their places; but in doing so we have regretted to see a man of letters like Señor de la Riega compromise his fair literary reputation by such an excursion which he could have had no interest to undertake, for it is really difficult to understand the object of so noisy a campaign.

Is not the glory of Columbus exclusively Spanish? Was it not to Spain he carried his great designs? Was it not in Spain they were entertained, and was it not there that he was put into a position to carry them out? Was it not in Spain he founded a family, and had he not become so thoroughly Spanish as to lose the use of his own mother-tongue? What matter then whether he were born in Pontevedra or Genoa? Columbus, in whatever city he first saw the light of day, belongs to Spain and can be claimed by none but her. To her he owes what he was, and it is to him she is indebted for that New World whose existence he had divined, and in whose quest he went until he found and gave her to his adopted country.

Henry Vignaud. 






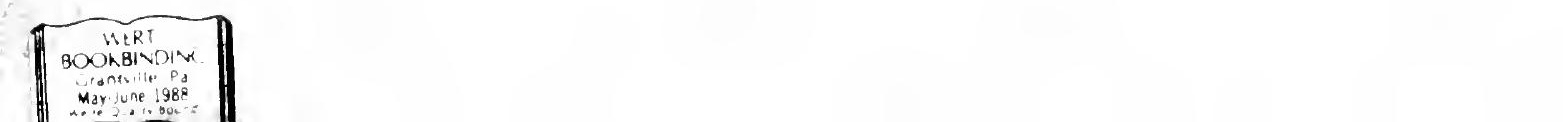


